\title{
New Report of Three Xanthid Crabs (Crustacea: Decapoda: Xanthidae) from Korea
}

\author{
Sang-kyu Lee ${ }^{1}$, Myung-Hwa Shin ${ }^{1}$, Tae Seo Park ${ }^{1,2}$, Won Kim ${ }^{1, *}$ \\ ${ }^{1}$ School of Biological Sciences, Seoul National University, Seoul 151-747, Korea \\ ${ }^{2}$ National Institute of Biological Resources, Incheon 404-170, Korea
}

\begin{abstract}
Many members of xanthid crabs have the black coloured fingers and are found easily in the intertidal or subtidal zone. Three xanthids, Danielea noelensis (Ward, 1934), Etisus anaglyptus H. Milne Edwards, 1834, and Gaillardiellus rueppelli (Krauss, 1843), are newly reported from Korean waters as a result of continuous taxonomic studies on crabs. Of these, the present specimen of D. noelensis has rather projecting angle on the antero-external border of the merus of the third maxilliped differed from that of the original description. The genus Danielea $\mathrm{Ng}$ and Clark, 2003 and the genus Etisus H. Milne Edwards, 1834 are also reported first time from Korean fauna. Their descriptions are provided with illustrations. Korean Xanthoidea now consists of 28 species belonging to 24 genera.
\end{abstract}

Keywords: Decapoda, Xanthidae, Danielea noelensis, Etisus anaglyptus, Gaillardiellus rueppelli, Korean fauna

\section{INTRODUCTION}

Many members of the family Xanthidae MacLeay, 1838 have the black colored fingers. Most of them occur in the Indo-West Pacific area and they are found easily in the intertidal or subtidal zone. They hide under the rocks or in sponges and other sessile invertebrates, and graze on algae or detritus.

Twenty-five species of 22 genera belonging to the family Xanthidae have been recorded in Korean fauna. Danielea noelensis (Ward, 1934), Etisus anaglyptus H. Milne Edwards, 1834, and Gaillardiellus rueppelli (Krauss, 1843) were collected by SCUBA diving, and they were new to Korean waters. The genus Danielea Ng and Clark, 2003 and the genus Etisus H. Milne Edwards, 1834 were also reported first from Korea. Their morphological descriptions are provided with illustrations. Now, Korean xanthoid crabs consist of 28 species of 24 genera.

\section{MATERIALS AND METHODS}

Materials examined in this study were preserved in 95\% ethyl alcohol, and deposited in the Marine Arthropod Depository
Bank of Korea (MADBK), Seoul National University. The specimens were observed under SZ 12 binocular stereomicroscope (Leica, Wetzlar, Germany). Drawings were made with the aid of Camera Lucida. Images were recorded using D7000 digital camera (Nikon Imaging Korea, Seoul, Korea), and developed with Helicon Focus software (Helicon Soft, Kharkov, Ukraine).

The abbreviations "cl," "cw," and "G1" refer to the carapace length from the front to the posterior dorsal margin of the carapace, to the width of the carapace measured at the widest part, and to the first gonopod of male, respectively. All characters were measured using metric dial calipers (Wiha, Monticello, MN, USA). The zones of the carapace (1-3M, 1F, 2F, 1-4L, and 1-2P) were divided according to Dana (1852) and Serène (1984). The classification follows that of $\mathrm{Ng}$ et al. (2008).

\section{SYSTEMATIC ACCOUNTS}

Order Decapoda Latreille, 1802

Family Xanthidae MacLeay, 1838

Subfamily Actaeinae Alcock, 1898

Genus Gaillardiellus Guinot, 1976
(C) This is an Open Access article distributed under the terms of the Creative Commons Attribution Non-Commercial License (http://creativecommons.org/ licenses/by-nc/3.0/) which permits unrestricted non-commercial use, distribution, and reproduction in any medium, provided the original work is properly cited.

\footnotetext{
*To whom correspondence should be addressed

Tel: 82-2-880-6695, Fax: 82-2-872-1993

E-mail: wonkim@plaza.snu.ac.kr
} 
1*Gaillardiellus rueppelli (Krauss, 1843) (Figs. 1, 2) Cancer (Aegle) rüppelli Krauss, 1843: 28, Pl. 1, fig. 1.

Paractaea ruppelli: Sakai, 1976: 451, fig. 242; Dai and Yang, 1991: 314, Pl. 40(6), fig. 162(1).

Gaillardiellus rueppelli: Guinot, 1976: 254, figs. 42A, 43A, 43a, 44B, 44b, Pl. 16, figs. 1, 1a; Serène, 1984: 118, Pl. 15F, fig. 71; $\mathrm{Ng}$ et al., 2008: 195.

Material examined. 1 우 (cl $25.4 \mathrm{~mm}$, cw $32 \mathrm{~mm}$ ), Korea: Jejudo, Isl. Munseom, 21 Jan 1997.

Comparative materials. Gaillardiellus orientalis (Odhner, 1925): 1 우 (cl 15 mm, cw 19 mm), Korea: Geoje-si, Isl. Hongdo, 17 Oct 2010; 1 శ (cl 13.8 mm, cw $19.1 \mathrm{~mm})$, Gyeongsangbuk-do, Ulleung-gun, Isl. Ulleungdo, 24 Jun 2007.

Gaillardiellus rueppelli (Krauss, 1843): $1 \sigma^{7}$ (cl 15 mm, cw $20 \mathrm{~mm}$ ), Madagascar: Ifaty.

Description. Carapace (Figs. 1, 2A) transversely oval; surface thickly covered with granules and short setae, interspersed with long setae; all regions divided into lobules by deep smooth grooves; $2 \mathrm{M}$ completely divided into two lobules; outer lobule convex and broader; $1 \mathrm{P}$ also well convex and circular. Front (Figs. 1, 2A) divided into two lobes by median V-shaped notch. Orbit (Figs. 1, 2A) with dorsal mar- gin convex. Anterolateral border (Figs. 1, 2A) composed of four convex lobes excluding external orbital angle: first and last smaller, second and third broader. Posterolateral border (Figs. 1, 2A) shorter than anterolateral one, and slightly concave. Third maxilliped (Fig. 2C) completely covering buccal orifice, bearing seta on surface; ischium subrectagular; merus subquadrate with seta, and angled on anterolateral border.

Chelipeds (Figs. 1, 2B) symmetrical, and covered with granules and long setae. Carpus massive, larger than propodus, and covered with tubercles separating by shallow grooves on upper surface. Propodus short and small, with 3 tubercles on dorsal surface, marked with transverse granulated carinae. Dactylus with tip bluntly round.

Ambulatory legs (Figs. 1, 2D, E) stout. Merus with long setae along anterior margin and granules on dorsal surface; first to third pairs relatively smooth. Carpus with longitudinal groove. Dactylus with tip claw-shaped.

Distribution. Australia, China, Indonesia, Japan, Kenya, Madagascar, Mauritius, Mergui Archipelago, Papua New Guinea, Persian Gulf, Philippines, Samoa, Singapore, South Africa, Tahiti, and Korea (the present study).

Remarks. The present specimen (Fig. 1) agrees with the description by Dai and Yang (1991). In Korean fauna, only

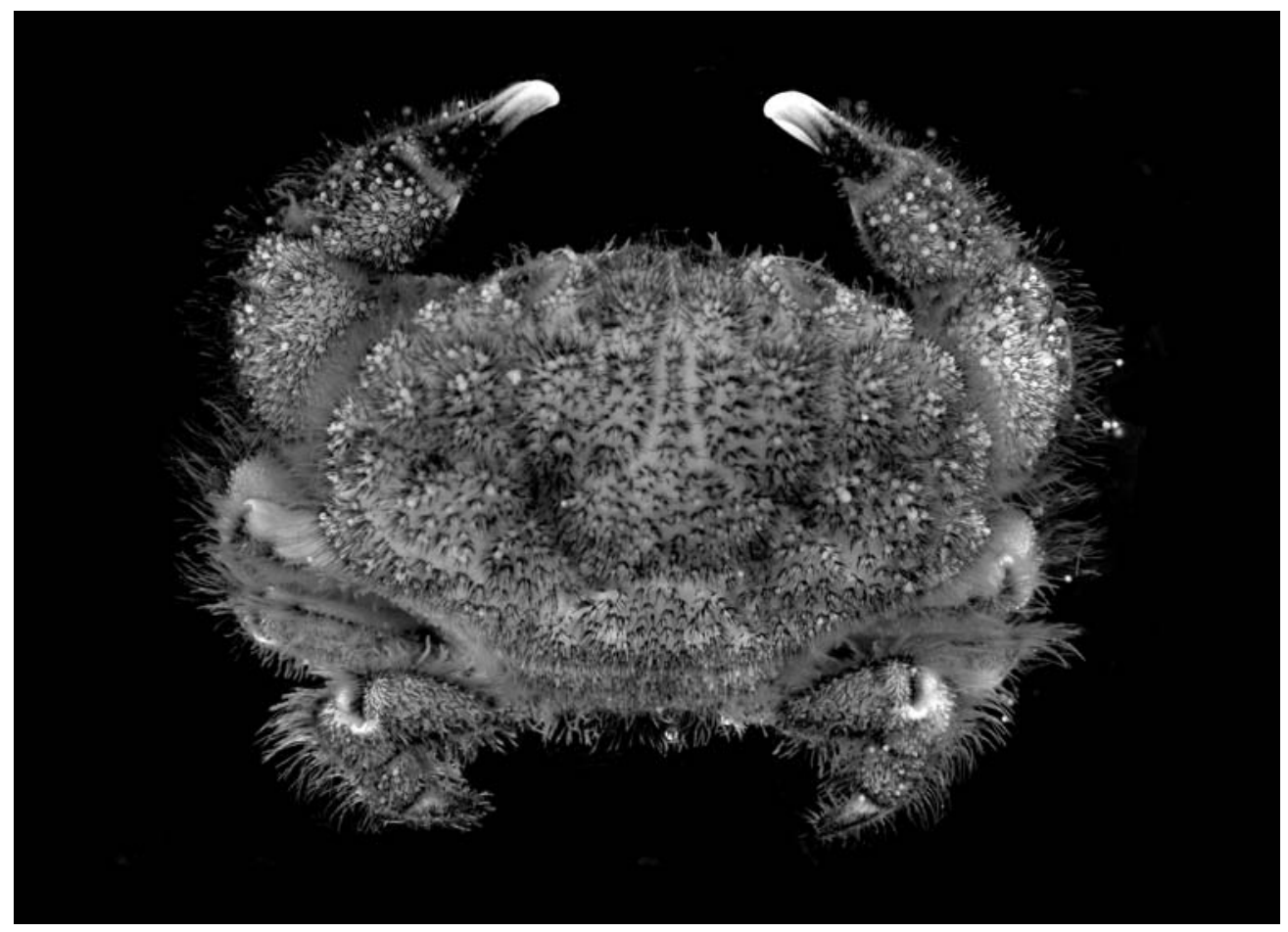

Fig. 1. Gaillardiellus rueppelli (Krauss, 1843), female, whole animal (cl $25.4 \mathrm{~mm}, \mathrm{cw} 32 \mathrm{~mm}$ ). cl, carapace length from the front to the posterior dorsal margin of the carapace; cw, width of the carapace measured at the widest part. 

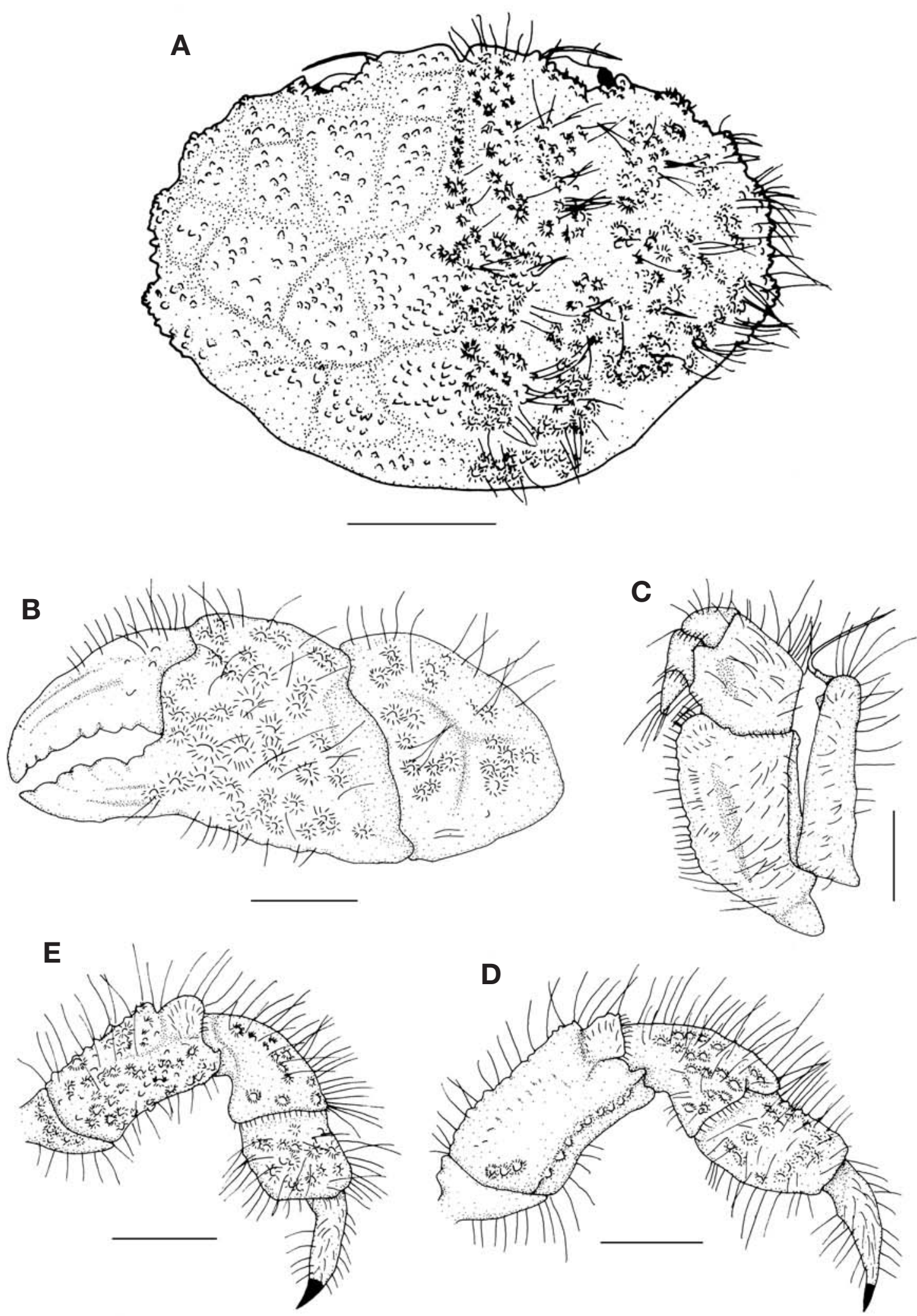

Fig. 2. Gaillardiellus rueppelli (Krauss, 1834). A, Carapace, dorsal view; B, Left cheliped, outer view; C, Left 3rd maxilliped; D, 3rd ambulatory leg, dorsal view; $\mathrm{E}$, 4th ambulatory leg, dorsal view. Note: seta on the left part of the carapace are omitted. Scale bars: $A=10 \mathrm{~mm}, B, D, E=5 \mathrm{~mm}, C=3 \mathrm{~mm}$. 
Gaillardiellus orientalis (Odhner, 1925) (Fig. 3) has been recorded in the genus Gaillardiellus. These two species are distinguished from each other in characters: presence or absence of tufts of long and plumose setae distributed on regions of their carapace (Serène, 1984) and shapes of G1 (Guinot, 1976). In the present study, G. orientalis has tufts of long setae on their carapace while G. rueppelli does not have. Identification using G1 is difficult because their G1 are quite similar.

The distribution of setae on the carapace of G. rueppelli is similar to that those of previously recorded Pilodius nigrocrinitus Stimpson, 1858 and Actaeodes hirsutissimus (Rüppell, 1830) from Korean fauna. G. rueppelli, however, is distinguished from previous two species because the genus Gaillardiellus has the deep and broader suture between sternite 3 and 4 (fig. 42A in Guinot, 1976; fig. 54D in Serène, 1984).

Subfamily Etisinae Ortmann, 1893

Genus ${ }^{1 *}$ Etisus H. Milne Edwards, 1834

${ }^{2 *}$ Etisus anaglyptus $\mathrm{H}$. Milne Edwards, 1834 (Figs. 4, 5) Etisus anaglyptus H. Milne Edwards, 1834: 411; Sakai, 1976:
456, fig. 246; Serène, 1984: 219(key), 223(key), 228, Pl. 32A, fig. 137; Dai and Yang, 1991: 324, Pl. 42(3); Ng et al., 2001: 27; Ng et al., 2008: 198.

Etisodes anaglyptus: A. Milne Edwards, 1873: 235; McNeill, 1968: 65.

Material examined. 1 우 ( $\mathrm{cl} 25.6 \mathrm{~mm}$, $\mathrm{cw} 37.5 \mathrm{~mm}$ ), Korea: Gyeongsangbuk-do, Uljin-gun, Deokcheon-ri, 25 Aug 2010, Park TS, by SCUBA diving.

Description. Carapace (Figs. 4, 5A) transversely oval, about 1.46 times as broad as long; surface not smooth, slight rugose with sparse pits; regions well defined by grooves: gastriccardiac regions with $\mathrm{H}$-shaped groove distinct. Front (Figs. 4, 5A) narrow, produced, 0.15 times as broad as carapace width, divided into two lobes by $\mathrm{V}$-shaped median notch. Orbital (Figs. 4, 5A, B) complete, very narrow orbital hiatus being completely filled up by prolonged lobule from basal antennal segment; inner angle obtuse and outer angle tubercular; inner angle of ventral margin very produced and visible from above. Third maxilliped (Fig. 5C) completely covering buccal orifice; ischium subrectagular; merus subquadrate. Anterolateral border (Figs. 4, 5A) armed with four teeth

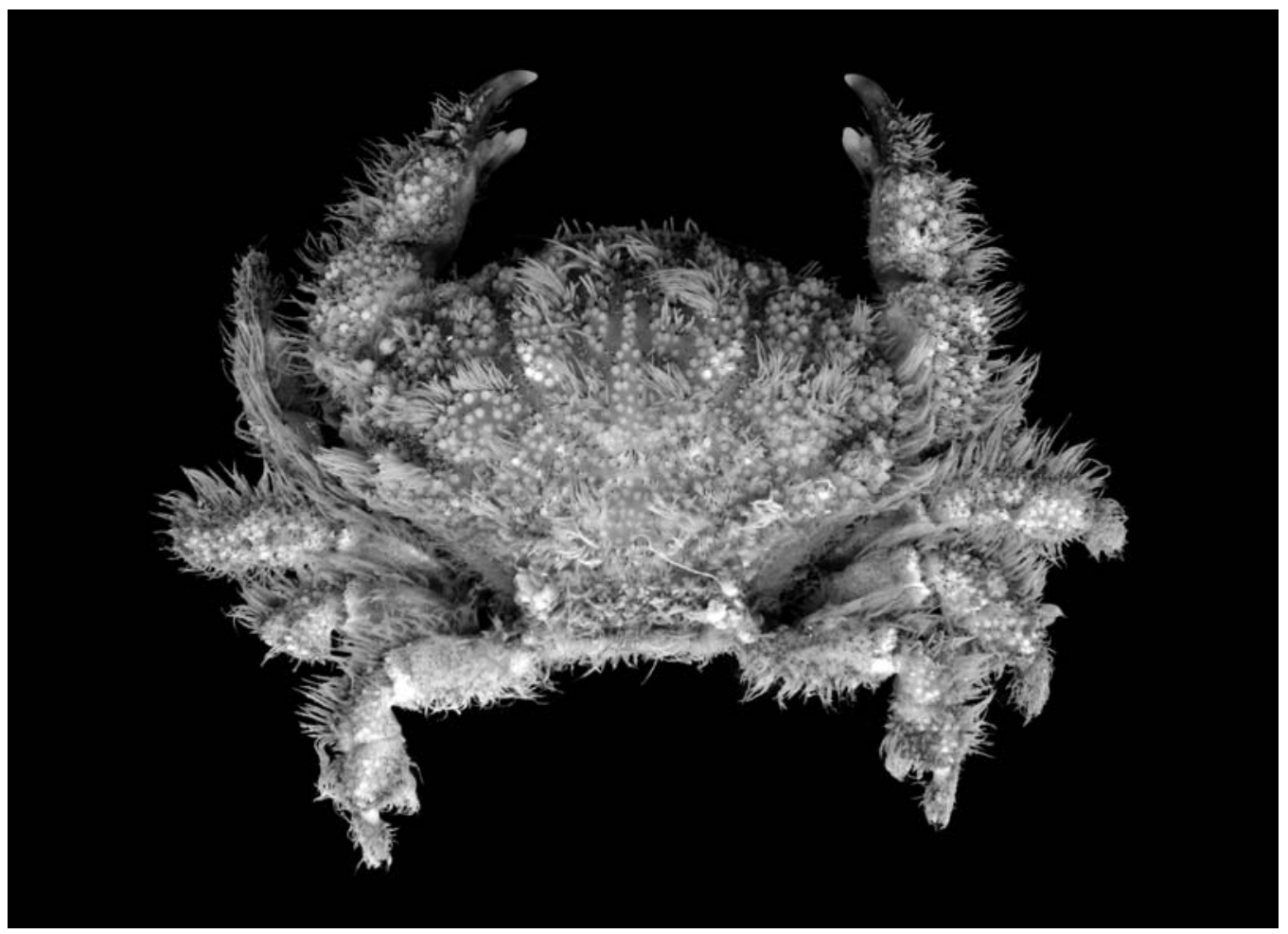

Fig. 3. Gaillardiellus orientalis (Odhner, 1925), female, whole animal (cl $15 \mathrm{~mm}, \mathrm{cw} 19 \mathrm{~mm}$ ). cl, carapace length from the front to the posterior dorsal margin of the carapace; $\mathrm{cw}$, width of the carapace measured at the widest part.

Korean name: ${ }^{1 *}$ 돋음부채게속, ${ }^{2 *}$ 돋음부채게 
exclusive of external orbital angle; first two obtuse, last two obtusely pointed and curved forward; transverse groove deep behind last teeth.

Chelipeds (Figs. 4, 5D) covered with fine granules except for ventral surface. Carpus with three tubercles on dorsal surface, six tubercles on outer surface, and two tubercles on inner surface. Propodus weakly compressed and bearing four or five tubercles on superior border and about six smaller ones on outer surface. Dactylus with four teeth on either inner margin; tip spoon-shaped, with a tuft of setae.

Ambulatory legs (Fig. 5E, F) stubby, with long hairs along both margins; merus and carpus with granular spines on anterior margins; carpus with granulated ridge on dorsal surface; propodus and dactylus also covered with granular spines.

Habitat. Rocky or stony beaches, under stones or in crevices of rocks, shallow waters.

Distribution. Australia, China, India, Japan, Madagascar, Red Sea, Samoa, Taiwan, Vietnam, and Korea (the present study).

Remarks. According to Dai and Yang (1991), and Sakai (1976), E. anaglyptus has an elongated basal antennal segment occupying the orbital hiatus, feebly developed frontal margin from the supra-orbital angles, and numerous long setae and granular spines on ambulatory legs. The characteristics of the present specimen agree well with their description.

Subfamily Euxanthinae Alcock, 1898

Genus ${ }^{1 *}$ Danielea $\mathrm{Ng}$ and Clark, 2003

2*Danielea noelensis (Ward, 1934) (Figs. 6, 7)

Medaeus noelensis Ward, 1934: 17, Pl. 1, fig. 1.

Paramedaeus noelensis: Sakai, 1976: 426, fig. 224; Serène, 1984: 90, Pl. 12F, fig. 51.

Danielea noelensis: Ng and Clark, 2003: 142, fig. 4; Ng et al., 2008: 198.

Material examined. $1 \sigma^{7}(\mathrm{cl} 9.5 \mathrm{~mm}$, cw $14.3 \mathrm{~mm})$, Korea: Jejudo, Isl. Beomseom, 6 Jun 2001.

Description. Carapace (Figs. 6, 7A) transversely oval; dorsal surface gently convex; regions densely covered with small, evenly sized rounded granules. Front (Figs. 6, 7A) weakly produced, divided into two broad lobes by small, narrow fissure. Orbits (Figs. 6, 7A) subparallel with frontal margin;

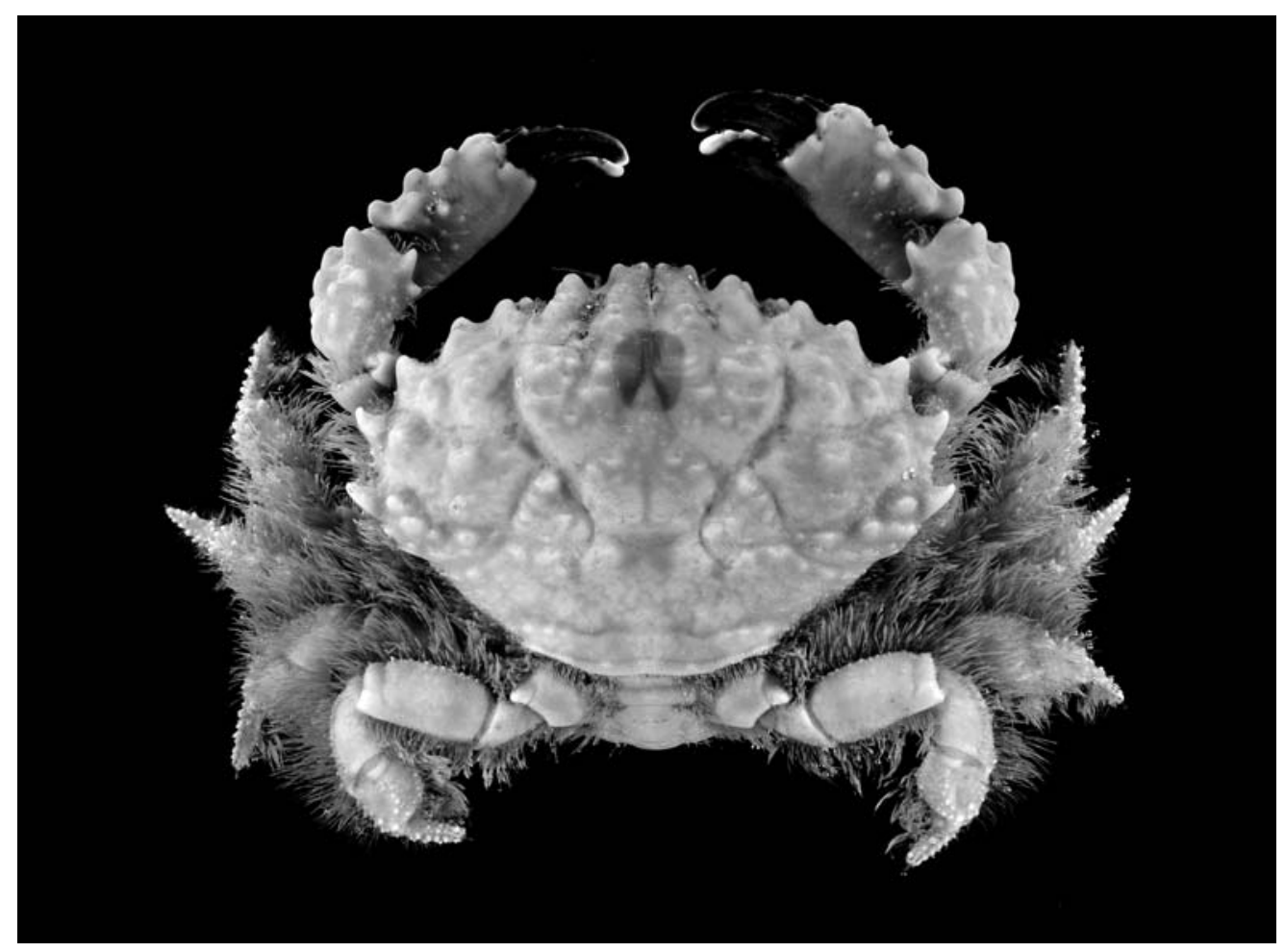

Fig. 4. Etisus anaglyptus $\mathrm{H}$. Milne Edwards, 1834, female, whole animal (cl $25.6 \mathrm{~mm}, \mathrm{cw} 37.5 \mathrm{~mm}$ ). cl, carapace length from the front to the posterior dorsal margin of the carapace; $\mathrm{cw}$, width of the carapace measured at the widest part.

Korean name: ${ }^{1 *}$ 잔물결부채게속, ${ }^{2 *}$ 잔물결부채게 

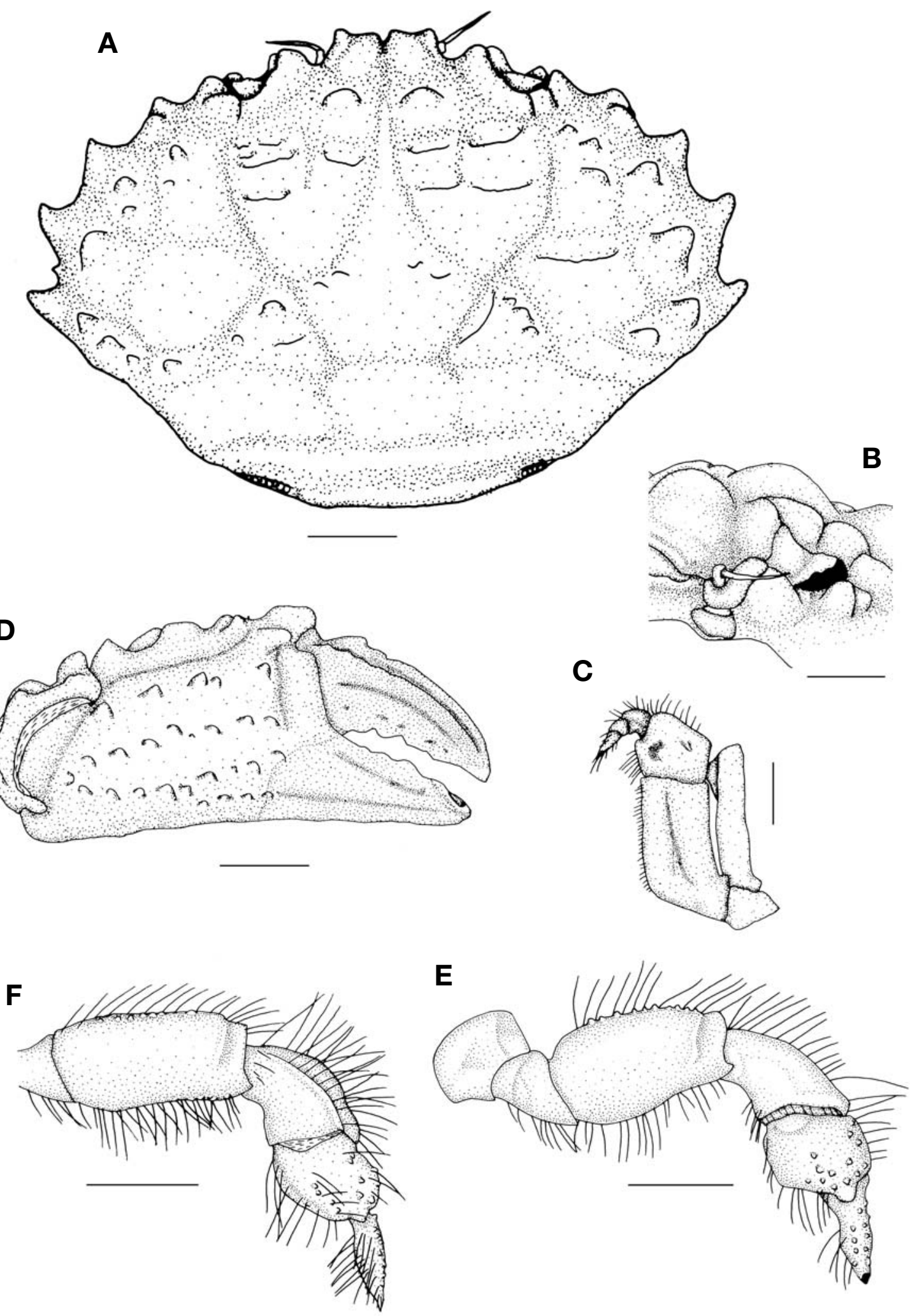

Fig. 5. Etisus anaglyptus $\mathrm{H}$. Milne Edwards, 1834. A, Carapace, dorsal view; B, Basal antenna segment, frontal view; C, Left 3rd maxilliped; D, Right cheliped, outer view; E, 3rd ambulatory leg, dorsal view; F, 4th ambulatory leg, dorsal view. Scale bars: A, D$\mathrm{F}=5 \mathrm{~mm}, \mathrm{~B}, \mathrm{C}=3 \mathrm{~mm}$. 


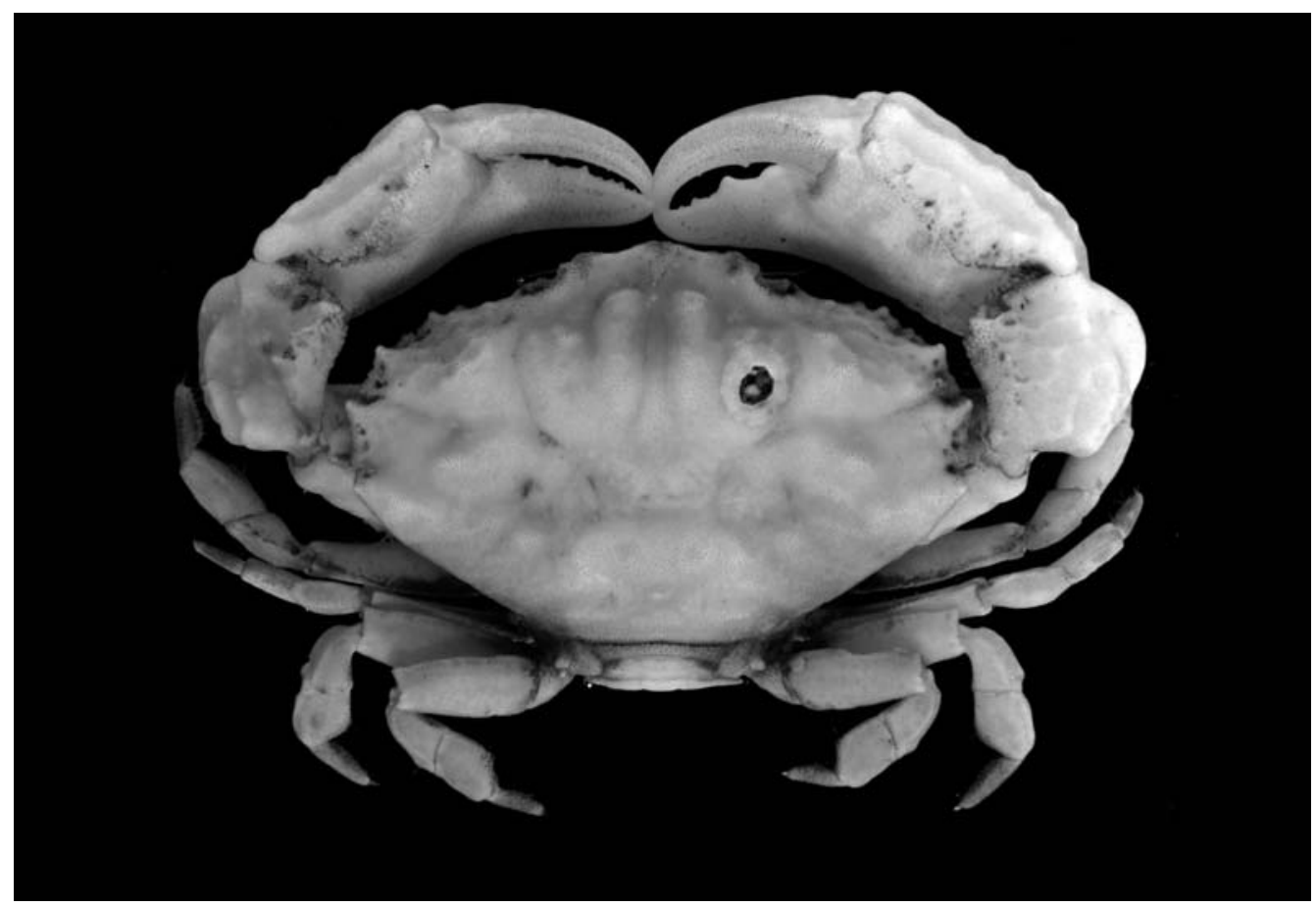

Fig. 6. Danielea noelensis (Ward, 1934), male, whole animal (cl $9.5 \mathrm{~mm}, \mathrm{cw} 14.3 \mathrm{~mm}$ ). cl, carapace length from the front to the posterior dorsal margin of the carapace; $\mathrm{cw}$, width of the carapace measured at the widest part.

inner supraobital tooth low and rounded; external orbital tooth low and undiscernible. Eyestalk granulated. Anterolateral border (Figs. 6, 7A) with four broad teeth; first tooth very low; next three teeth low, each with median prominence. Posterolateral border (Figs. 6, 7A) gently convex to almost straight, wider than frontal margin. Basal antennal segment subrectangular, free but filling orbital hiatus. Surface of third maxilliped (Fig. 7D) densely covered with evenly sized small rounded granules; merus squarish and rather projecting on anteroexternal angle. Thoracic sternum (Fig. 7E) relatively broad, surface entirely; suture between sternites 2 and 3 welldeveloped, complete; suture between sternites 3 and 4 prominent but becoming shallow medially.

Chelipeds (Figs. 6, 7B, C) elongate; outer surfaces densely covered with evenly sized granules. Dorsal margin of merus granular. Carpus rounded rugose on dorsal surface, inner angle with one prominent rounded tooth and several tubercles anteriorly. Propodus with prominent uneven, almost subpetaloid crest on subdorsal inner surface. Right cheliped with two teeth and pronounced curved basal cutting tooth on cutting edge of dactylus. Left cheliped with fingers more slender, cutting edges blade-like, each with two or three teeth and two or three denticles.

Ambulatory legs (Figs. 6, 7F, G) with all segments unarmed, almost glabrous; surfaces densely covered with evenly sized small rounded granules. Merus entirely cristate on anterior margin. Carpus with distal part of dorsal margin subcristate, produced into rounded tooth.

Abdomen of male (Fig. 7I) with segments 3-5 completely fused, sutures separating segments not discernible, lateral margins entire, without clefts; segments 1-3 trapezoidal, segment 6 rectangular, lateral margins gently concave, subparallel; telson semicircular, lateral margins distinctly convex, tip rounded; surfaces of all segments covered with numerous small evenly sized granules.

First gonopod of male (Fig. 7H) relatively stout, gently curved, tip blunt; lateral margins lined with short spines and long plumose setae on disto-dorsal margin.

Distribution. Christmas Island, Japan, Madagascar, Mauritius, Philippines, Red Sea, Samoa, Tahiti, and Korea (the present study).

Remarks. The present specimen agrees well with the description of $\mathrm{Ng}$ and Clark (2003) except for antero-external angle of merus of third maxilliped (Fig. 7D). In their Danielea noelensis, antero-external angle is not projecting but that of the present specimen is rather projecting.

Danielea noelesis is similar to Medaeops granulosus (Haswell, 1882) in Korean fauna. These two species have lamelliform surfaces of the carapace and the upper margins of the chelipeds, and cristiform on the anterior margin of the 

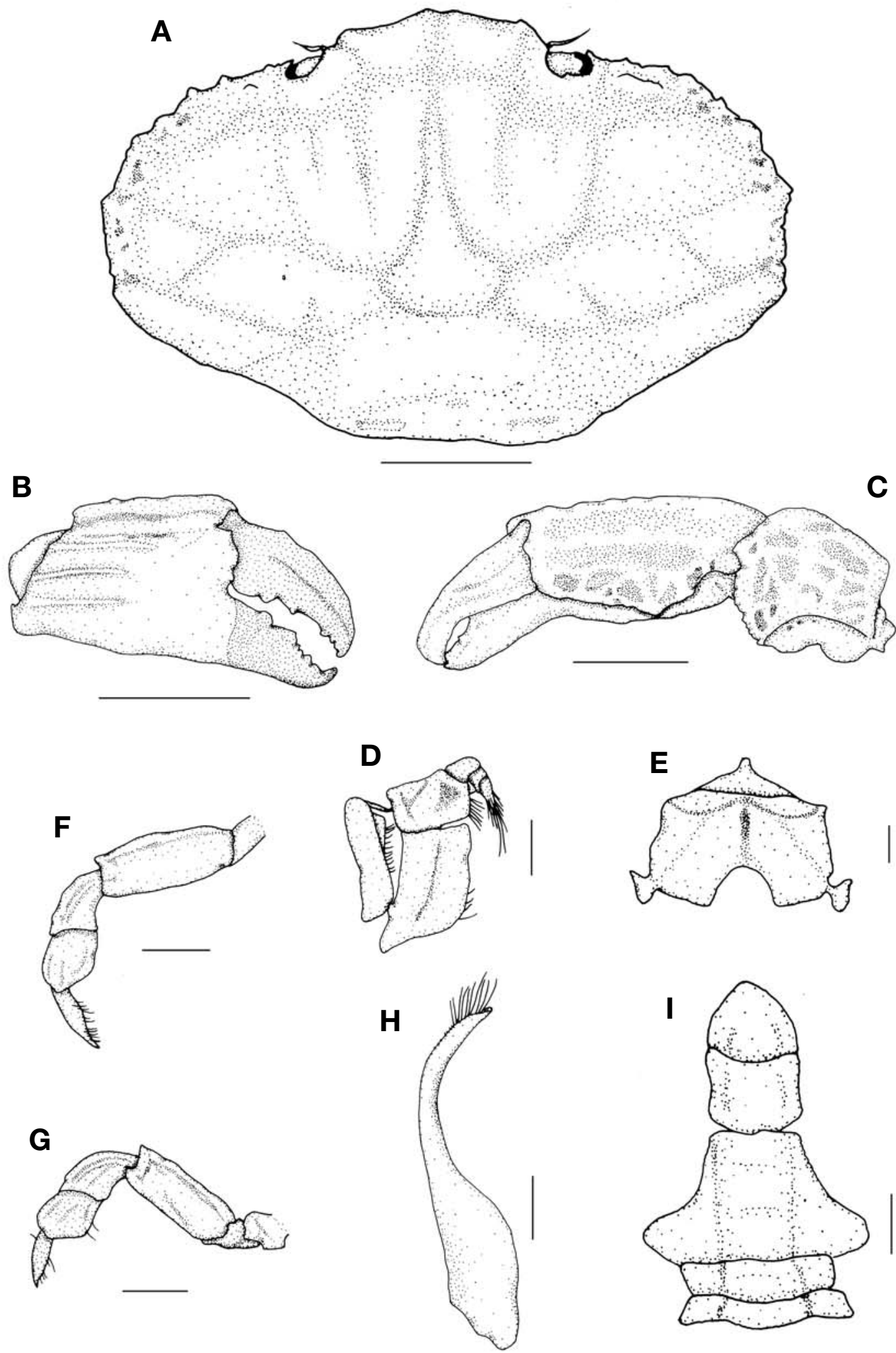

Fig. 7. Danielea noelensis (Ward, 1934). A, Carapace, dorsal view; B, Right cheliped, outer view; C, Right cheliped, dorsal view; D, Right 3rd maxilliped; E, Sternites 1-4; F, 3rd ambulatory leg, dorsal view; G, 4th ambulatory leg, dorsal view; H, Left first gonopod, ventral view; I, Abdomen of male. Scale bars: $A, C=3 \mathrm{~mm}, B=5 \mathrm{~mm}, \mathrm{D}, \mathrm{E}, \mathrm{I}=1 \mathrm{~mm}, \mathrm{~F}, \mathrm{G}=2 \mathrm{~mm}, \mathrm{H}=0.5 \mathrm{~mm}$. 
merus of each ambulatory leg. However, D. noelensis bears almost subpetaloid crest on subdorsal inner surface of the right cheliped while $M$. granulosus does not have this crest.

\section{ACKNOWLEDGMENTS}

The authors thank Prof. Peter K. L. Ng and Dr. Jose C. E. Mendoza (National University of Singapore) for allowing the first author to use facilities and comments during visit. This work was supported by a grant from Marine Biotechnology Programme Funded by Ministry of Land, Transport, and by Basic Science Research Program through the National Research Foundation of Korea (NRF) funded by the Ministry of Education, Science and Technology (2011-0009155).

\section{REFERENCES}

Dai A, Yang S, 1991. Crabs of the China seas. China Ocean Press, Beijing, pp. 1-608.

Dana JD, 1852. Crustacea. Part I. United States Exploring Expedition: during the years $1838,1839,1840,1841,1842$, under the command of Charles Wilkes, U.S.N., 13:1-685.

Guinot D, 1976. Constitution de quelques groupes naturels chez les Crustacés Décapodes Brachyoures. I. La superfamille des Bellioidea Dana et trois sous-familles de Xanthidae (Polydectinae Dana, Trichiinae de Haan, Actaeinae Alcock). Mémoires du Muséum National d'Histoire Naturelle, Nouvelle Série, Séries A, Zoologie, 97:1-308 (in French).

Haswell WA, 1882. Catalogue of the Australian stalk- and sessile-eyed Crustacea. The Australian Museum, Sydney, pp. 1-324.

Krauss F, 1843. Die Südafrikanischen Crustaceen, Eine Zusammenstellung aller bekannten Malacostraca, Bemerkungen über deren Lebensweise und geographiche Verbreitung, Nebst Beschreibung und Abbildung mehrer neuen Arten. E. Schweizerbart'sche Verlagsbuchhandlung, Stuttgart, pp. 1-68.

McNeill FA, 1968. Crustacea, Decapoda and Stomatopoda. Scientific Reports Great Barrier Reef Expedition 1928-29, 7:1-98.

Milne-Edwards H, 1834-1840. Histoire naturelle des Crustacés, comprenant l'anatomie, la physiologie et la classification de ces animaux. Librairie Encyclopédique de Roret. Vol. 1. Librarie Encyclopédique de Roret, Paris, pp. 1-468.

Milne Edwards A, 1873. Recherches sur la faune carcinologique de la Nouvelle-Calédonie. Part II. Groupe des Cyclométopes Portuniens. Nouvelles Archives du Muséum National d'Histoire Naturelle, Paris, 9:155-332.

Ng PKL, Clark PF, 2003. Three new genera of Indo-West Pacific Xanthidae (Crustacea, Decapoda, Brachyura, Xanthoidea). Zoosystema, 25:131-147.

Ng PKL, Guinot D, Davie PJF, 2008. Systema Brachyurorum: Part I. An annotated checklist of extant brachyuran crabs of the world. The Raffles Bulletin of Zoology, Supplement, 17:1-286.

Ng PKL, Wang CH, Ho PH, Shih HT, 2001. An annotated checklist of brachyuran crabs from Taiwan (Crustacea: Decapoda). National Taiwan Museum Special Publication Series, 11:1-86.

Odhner T, 1925. Monographierte Gattungen der Krabben-familie Xanthidae. I. Göteborgs Kungliga Vetenskaps-och VitterhetsSamhälles Handlingar, 4 Series, 29:1-92 (in German).

Rüppell ES, 1830. Beschreibungen und Abbildungen von 24 Arten kurzschwänzigen krabben, als Beiträge zur Naturgeschichte des Rothen Meeres. H.L. Brönner, Frankfurt a.m., pp. 1-28.

Sakai T, 1976. Crabs of Japan and the adjacent seas. Kodansha Ltd., Tokyo, pp. 1-773.

Serène R, 1984. Crustacés Décapodes Brachyoures de l'Ocean Indien Occidental et de la Mer Rouge, Xanthoidea: Xanthidae et Trapeziidae. Avec un addendum par Crosnier, A: Carpiliidae et Menippidae. Faune Tropicale, 24:1-349.

Stimpson W, 1858. Prodromus descriptionis animalium evertebratorum, quae in Expeditione ad Oceanum Pacificum Septentrionalem, a Republica Federata missa, Cadwaladaro Ringgold et Johanne Rodgers ducibus, observavit et descripsit. Pars IV. Crustacea Cancroidea et Corystoidea. Proceedings of the Academy of Natural Sciences of Philadelphia, 10:31-40.

Ward M, 1934. Notes on a collection of crabs from Christmas Island, Indian Ocean. Bulletin of the Raffles Museum, 9:528 .

Received March 9, 2012

Revised April 9, 2012 Accepted April 12, 2012 